This item was submitted to Loughborough's Research Repository by the author.

Items in Figshare are protected by copyright, with all rights reserved, unless otherwise indicated.

\title{
Performing citizenship on YouTube: activism, satire and online debate around the anti-Islam video Fitna
}

PLEASE CITE THE PUBLISHED VERSION

http://dx.doi.org/10.1080/17405904.2010.511831

PUBLISHER

Routledge (@) Taylor \& Francis)

VERSION

AM (Accepted Manuscript)

LICENCE

CC BY-NC-ND 4.0

\section{REPOSITORY RECORD}

van Zoonen, Liesbet, Farida Vis, and Sabina Mihelj. 2019. "Performing Citizenship on Youtube: Activism, Satire and Online Debate Around the Anti-islam Video Fitna". figshare. https://hdl.handle.net/2134/7383. 
This item was submitted to Loughborough's Institutional Repository (https://dspace.lboro.ac.uk/) by the author and is made available under the following Creative Commons Licence conditions.

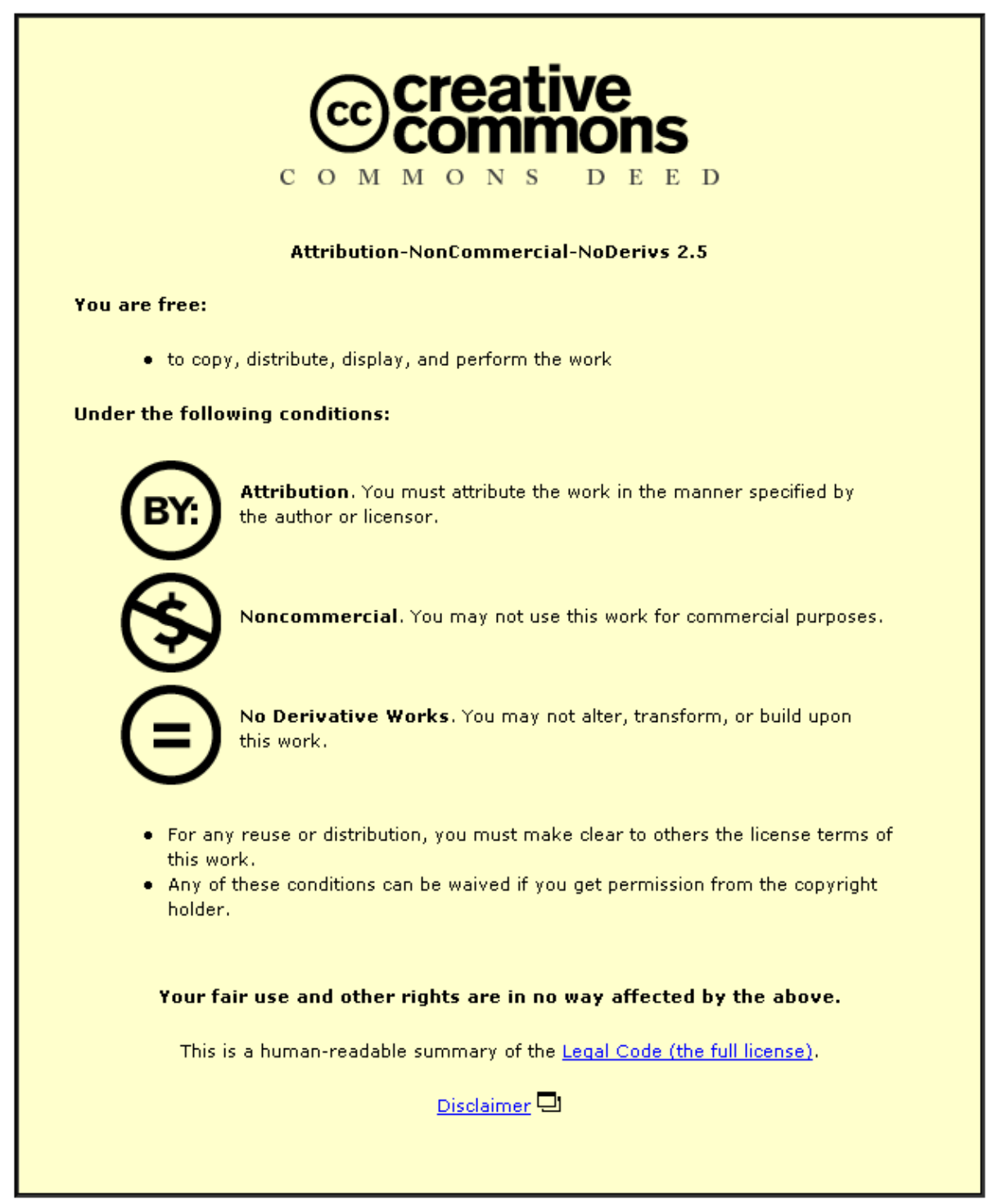

For the full text of this licence, please go to: http://creativecommons.org/licenses/by-nc-nd/2.5/ 
Performing citizenship on YouTube: activism, satire and online debate around the anti-Islam video Fitna.

Liesbet van Zoonen, Loughborough University (corresponding author: e.a.van-zoonen@lboro.ac.uk)

Farida Vis, Loughborough University

Sabina Mihelj, Loughborough University

Please refer to this paper as published in:

Critical Discourse Studies, vol. 7(4), p. 249-262, 2010. 

Fitna.

\section{Abstract:}

In this article we examine the hundreds of videos that were posted to YouTube in response to the fierce anti-Islam video Fitna. We use this case to analyse whether and how the participatory opportunities of the digital technologies invite performances of citizenship, especially with respect to the articulation of religious and/or political identity. The sheer numbers of YouTube activities (videos, views and comments) demonstrated that this was not at all a marginal phenomenon within the wider Fitna and Wilders controversy, making the question as to what these videos mean, or - to be more precise - for which contexts the posters make them meaningful, all the more pressing. We used the concepts of 'voice', 'performance' and 'citizenship' to approach this issue and found that the video genres unique to visual digital culture (tagging/jamming, cut-and-mix and vlogs) each invited their own kinds of political and religious performances, and assumed particular traits and interests of their audience. The most common YouTube reaction for Muslims was to upload copies of videos that expressed their own understanding of Islam as a peaceful religion in contrast to the picture drawn by Wilders. The jamming videos saying sorry were unique digital means of activism, enabling a particular participation in the controversy around Fitna that assumed a global audience open to apology. The cut-and-mix videos, appeared to be especially welcome means for satire and parody and appealing to audience emotions, but also for the deconstruction of Fitna which addressed audience cognitive competence. Vlogging about Fitna, was often part of a more regular practice of video production that was individually or institutionally maintained. We conclude that the particular articulations of religious and political identities, with different modes of audience address assume a connectedness between dispersed people in which new forms of(unlocated) citizenship emerge. 
Citizenship in today's multicultural, multireligious, and multimedia societies is confronted with a myriad of political and conceptual challenges that are not easily understood in the standard frameworks of citizenship as a legal, political or social status, or of citizenship as an acknowledged cultural identity. Nowhere is this clearer than in the charged debates and confrontations about the position of Islam and Muslims in predominantly secular or Christian societies. In this article we use one such confrontation to demonstrate how the current multimedia environment necessitates a wider understanding of citizenship in which digital practices and occasional online acts are included and assessed as performances of citizenship. Our starting point is the Dutch fierce anti-Islam video Fitna, produced in 2008 by a member of the Dutch parliament, Geert Wilders, and released through a video-sharing website (LiveLeak) on the Internet. The film contained verses from the Quran, cut with footage of the terrorist attacks in New York and Madrid, fragments from notorious anti-Islam films such as Obsession: Radical Islam's War against The West, and The Violent Oppression of Women in Islam, images and statistics suggesting the Islamization of The Netherlands and Europe. ${ }^{1}$ In the Netherlands and across the world, many Muslims and other critics expressed their anger in various ways, ranging from diplomatic questions to violent street protest. The latter was covered by international news media and therewith, from the beginning, the release of Fitna became an issue that exceeded the boundaries of the Dutch nation state. The Dutch MP himself eagerly nurtured the controversy by recurrently staging international arguments: despite a ban of the Home Office on him coming to the UK to introduce Fitna in The House of Lords in early February 2009, Wilders tried to enter the country nevertheless, with over 50 journalists in his wake who witnessed how the immigration officers refused him. After successfully appealing the ban, his visit to the House of Lords, in October 2009, caught wide media attention once again, although significantly less than when he had been refused entry. When the Turkish authorities declared in late 2009 that they would not receive a Dutch parliamentary delegation if the controversial MP was part of it, Wilders was quick to stir up the incident by claiming Turkish intervention in Dutch democratic politics.

Beyond these highly visual confrontations of the political elites, ordinary citizens have also engaged in the pro and contra Fitna arguments using the many opportunities of the Internet to communicate their views to dispersed audiences. Apart from debates on blogs, fora, bulletin boards and other online spaces enabling discussion and demonstration, thousands of home made videos were uploaded either in protest or support of Wilders and Fitna, suggesting that video upload channels have become important arenas for political activity and communication. In this article we examine the videos that were posted to YouTube in order to analyse whether and how the participatory

\footnotetext{
${ }^{1}$ For a more detailed analysis of the film, especially from the perspective of gender, see Vis, Van Zoonen, Mihelj (2010).
} 
opportunities of the digital technologies invite performances of citizenship, especially with respect to the articulation of religious and/or political identity, which is a core issue in Fitna and in the video responses to it. ${ }^{2}$ Before we present our data, we will introduce the theories that inform our approach and research questions.

\section{Voice and the performance of citizenship}

Coverage of the Fitna controversies in the Dutch and UK offline news media (press and television) was typified by two things: first, reports, analyses and comments focused on the problems that Wilders had to get his video distributed as well as whether public broadcasters in the Netherlands had the right to refuse to show the film; moreover, whether the ban by the UK Home office was appropriate; or indeed whether the Turkish government could legitimately decline to receive Wilders. The coverage thus focused much more on the issue of freedom of speech than on the film's portrayal of Islam (Ruigrok et al, 2009; Knott, Poole and Taira, 2010). Wilders himself has successfully exploited an image of himself as relentless freedom fighter whose ideas and life are under continuous siege of Islamist terrorists; he is under $24 / 7$ protection of five security guards. It gets him the support of many people who do not have a strong anti-Islam sentiment, but who feel that everybody should be able to speak their mind. The second feature of mainstream news coverage is that the debate is conducted by the societal elite: cabinet members, party leaders, academics, religious leaders and the opinion makers of Dutch and UK civil society dominate the news pages and programs. Ordinary Muslims are hardly visible as actors who might have a say in this matter (cf. Ruigrok et al, 2009; Knott, Poole and Taira, 2010). The absence of ordinary citizens, however, is not particular to the Fitna controversy but is a generic feature of all mass mediated news whether about Islam (Poole and Richardson 2006; Richardson, 2004), or about other matters (Ericson et al., 1989).

Within this context of a news agenda that limited the debate to elite actors who predominantly focus on freedom of speech, it is not surprising that the Internet offered a much used opportunity for people to present their particular take on Fitna. The democratic affordances of the Internet have always been a key appeal to political activists and scientists alike. From its very early years as a public medium, the Internet has attracted grass roots activism, bottom-up discussions, and religious reflection (see Chadwick and Howard, 2009, for a useful overview). In fact, religion was and is one of the most important reasons for people to go online, look for shared religious and spiritual

\footnotetext{
${ }^{2}$ The research was funded by the AHRC and ESRC (UK) in the context of their Religion and Society Program, grant number AH-G016631-1. More information about the project can be found on: http://www.lboro.ac.uk/departments/ss/research/FITNA/index.html
} 
experiences and engage in communal activities (e.g. Barna, 2001; Bunt, 2009; Hoover, Schofield Clark and Rainie, 2004). In relation to Web 2.0, Paolilli (2008) has recently found that religion (Christianity and Islam in particular) forms a significant cluster among the material people upload on YouTube. While the initial euphoric discourses of the Internet as a medium that would open up true democratic exchange, build new and global communities and dismantle repressive structures and identities (e.g. Rheingold, 1991, 2000) have made way for a more empirically grounded understanding of only modest and situated participatory potential of the Internet (e.g. Hirzalla, 2007), fundamental issues as to who can speak online, in what way, for and to whom are still in full theoretical flux, as is the question of who is actually listening in this cacophony of voices.

The sociological concept of 'voice', as developed in Hirschman's (1970) classic treatise of options for participation is a useful starting point for theoretically positioning our examination of the YouTube responses to Fitna, but simultaneously identifies the shortcomings of traditional theories for thinking about global and visually performed citizenship. Hirschman claims that members of organisations but also, for instance, consumers in relation to consumption have three mutually related options when they are dissatisfied: exit (departure, which can be physical but also emotional), voice (providing feedback) or loyalty (acceptance). The greater the opportunities of voice, the lesser the probability of exit and the more chance of loyalty, Hirschman suggests, and vice versa. Through such continuous interaction of participatory options, the unit in which the interaction is embedded improves and maintains itself. While Hirschman's framework has successfully been used in many different academic disciplines, its key feature that there needs to be an entity with which one can interact - which listens to exit, voice and loyalty, so to speak - makes it not simply applicable to the global Fitna controversy. Conceptualizing the YouTube videos as 'voices' in the Hirschman sense produces the question as to what or in which entity these voices are speaking, and who - if anyone - is listening? While some of the videos may well be addressed to Wilders, to his political party, or the Dutch state, it is doubtful whether these entities are interested in listening and hence participating in the exchange. ${ }^{3}$

This tension in the usability of the concept of 'voice' can be partly overcome by turning it into an empirical question: who or what do the YouTube producers of the videos address? Yet, given the outcomes of other kinds of research about the Internet as a discussion platform, it can be expected that some or even many of these videos are simply there to make a statement that is relevant to the participant who may not be fundamentally interested in whether or how it is listened to. Van Zoonen at al. (2007), for instance, analysed the discussions on the bulletin boards of the popular Dr Phil US

\footnotetext{
${ }^{3}$ It is telling, in this respect, that the formal organisation of Wilders Freedom Party, does not allow for membership; financial donations are the only formal means of participation possible.
} 
television talk show that had invited the 2004 candidates for the US presidency to talk about their family lives. The call of the host to his audience to go online and share their own family experiences notwithstanding, the ensuing discussions focused on political issues such as the war in Iraq, or the state of the economy. Many of the participants only posted one message declaring their position, while other more prolonged discussions were conducted in sarcastic and condescending ways, aimed at silencing other participants rather than getting them to listen. The authors conclude, therefore, that these boards provided a space for simple declarations of political standpoints as much as they offered a platform for discussion about them. This particular demonstrative nature of Internet discussions, have led many authors to be cynical about the democratic potential of the Internet, claiming that it provides a platform without an audience, and produces talk without consequence. Keren (2006), for instance, claims in his analysis of the blogosphere that blogging might be seen as an expression of dissatisfaction with 'social control and manipulation by powerful political, corporate and media forces' (p. 149), and 'an attempt to restore a degree of authenticity, expressing some inner truth' (ibid). It is, however, a truth without impact, according to Keren, 'largely because of the virtual nature of the endeavor' (p. 152) which would divert bloggers into a fantasy world of words that do not ask nor need a response from the powers they resist.

Such a dark vision of Internet voices is built on the assumption that a voice is only meaningful if someone listens. Yet, current developments in citizenship theory offer an alternative understanding of such voices, namely as performances that are meaningful in themselves, that should be interrogated for what they achieve, not only for a possible audience but also for the speakers themselves. Schudson's (1998) analysis of the historical developments of the particular activities involved in voting offers a clear and historically grounded explanation of such performative nature of citizenship. Like Austin's classic theory of speech acts asks what is accomplished by saying something (rather than asking what cognition, opinion, emotion or attitude is reflected), analyzing citizenship as performance directs the analysis to the deed, instead of the doer. Citizenship can thus be conceptualized as brought into being through embedded practices and routines, as well as occasional acts and interactions (cf. Isin en Nielsen, 2008). Citizens are produced by these practices and acts, in addition to having a preset status or identity that makes or unmakes them as citizens. In other words, by doing citizenship one becomes a citizen, much like poststructuralist identity theory claims that by doing gender one becomes a woman or a man (e.g. Butler, 1990).

Such a concept as citizenship as performative is especially relevant in contexts where there is no preset geographical entity or polity to be part of, particularly with respect to issues of global relevance and interest such as Fitna. In line with public sphere theory we could argue that public debates on such global matters cannot be considered fully legitimate if they do not allow for equal 
exchange with all affected, regardless of formal citizenship (cf. Frazer 2007). For obvious reasons, traditional media, operating within nationally-bounded communicative spheres, are not particularly well equipped for complying with the 'all affected' principle when dealing with issues of transnational relevance. Indeed, both in the UK and in Netherlands, mainstream debates about Fitna largely excluded Muslims (Ruigrok et al, 2009; Knott, Poole and Taira, 2010). While not without its own drawbacks, YouTube proved well-suited for enabling an exchange among a wide range of those affected by Fitna, serving as a platform for a virtual and dispersed community constructed and defined through the articulation and interpretation of Fitna and Geert Wilders. Through making and uploading a video, posters performed an act or practice which constitutes them as part of this placeless public. Even if no-one is paying attention to this performance, the first relevance is nevertheless for the actor him or herself, who takes him or herself seriously as a stakeholder in a controversy that is otherwise played out on the distant stages of the mass media. Van Zoonen (2005, 2007) has analysed online discussions about Hollywood and other political film and TV fiction in a similar vein, approaching the individual comments in these discussions as performances through which people construct 'political selves', that can be ideological, reasonable or utopian (see also Eliasoph, 1998). In the context of religion, it is likely that online postings (whether verbal or visual) also involve the performance of a religious self, inserted in or taking issue with religious authority (cf. Lövheim and Linderman 2005, Cheong, Halavais and Kwon, 2008). Since Fitna's message is that Muslims cannot be full citizens in contemporary Dutch society on their own terms and must be fully assimilated, and the same applies to other societies with a Christian-Judeo tradition, according to Wilders, their video responses on YouTube may, in fact, involve a performance that inserts them both as citizens within a national context and debate, as well as within the global controversies around Islam, and moreover as legitimate interpreters of their own religion.

Approaching the YouTube videos as performances through which people perform a political or religious self, makes it possible to put the question of who is actually listening temporarily between brackets, ${ }^{4}$ and focus instead on who participates and how. While Isin and Nielsen pertain that it is necessary to ask how these performances gain audibility and visibility (p.3), the preceding issue, and our first research question, is what kind of selves people produce through uploading their videos against or in favor of Fitna. In addition, a second relevant question is whether these videos can also be considered as performances of citizenship in this placeless community constituted by Fitna. Therefore, we cannot only examine how the posters claim their right to speak and perform their political and religious selves, but also need to assess in which context they assume their

\footnotetext{
${ }^{4}$ This is, however, a question we take up in a subsequent part of the research, about the views of, comments on and interaction between the videos.
} 
performance takes place and becomes meaningful. It is in this latter articulation with imagined or real audiences that new dimensions of citizenship may emerge. With those two questions we will approach the videos posted to YouTube in response to Fitna.

\section{Method}

We began looking at the YouTube videos already before Fitna's release on March 28, 2008. Wilders had announced his film four months before its release, and in the run-up to the actual release there was already considerable activity on YouTube. A first systematic search on YouTube in April 2008 delivered 3190 hits for the search term 'Fitna'. When adding 'Wilders' to this search, the amount of hits went down to $2140 .{ }^{5}$ When revisiting YouTube for the research purpose in September and December 2008, some videos had been removed while the total number of hits for 'Fitna' had gone up to over 6000; 'Fitna Wilders' produced over 2300 hits (see Van Zoonen, Hirzalla, Müller, 2009). To counter the variability of the material we developed a customized e-research tool that prevented double-counts by identifying unique upload codes and that automatically coded all metadata such as date of upload, country of origin and gender as registered by the poster (for detailed information about the e-research tool see Vis et al., 2010) ${ }^{6}$. Through a new search using ten different keyword combinations (including 'Fitna Wilders') and entering them in to the e-tool in September 2009, we identified 1413 unique uploads that form our corpus for analysis. Most videos were uploaded in February, March, April and May of 2008 and we limited our analysis here to the 776 videos uploaded in these months. ${ }^{7}$

We conducted a quantitative and qualitative content analysis using different indicators and data to assess whether and how these videos claim their right to speak and which audiences they assumed. In order to get an overall view of the videos and a general sense of their features, we made a quantitative inventory based on the metadata from the e-tool (date of upload, gender, age, religion and country of origin as registered by the poster) and manual coding of a limited number of variables: length of the video, position of the video on Islam (positive, negative, unclear), position of the video on Fitna (positive, negative, not about Fitna, unclear), number of views, number of comments and the 'genre' of the video. To code the genres, we used categories that were developed

\footnotetext{
${ }^{5}$ When repeating this procedure on Google.video we got 2875 hits for 'Fitna', and 1781 hits for 'Fitna' combined with 'Wilders'; we therefore limited further searches to YouTube, which seemed to be most comprehensive.

${ }^{6}$ The e-research tool was developed in collaboration with Mike Thelwall, Professor in Information Science at Wolverhampton University, where among other things he is the head of the Statistical Cybermetrics Research Group (http://cybermetrics.wlv.ac.uk/).

${ }^{7}$ Obviously there is a long period between the first videos in early 2008 and the moment that we stabilized our data in September 2009. Funding for the research, which made this more systematic approach possible became available from June 2009.
} 
in a pilot study in which we made a bottom-up, constant comparison of the videos (Van Zoonen, Hirzalla, Müller, 2009) ${ }^{8}$ :

\section{Table 1. Genres in the YouTube responses to Fitna}

\begin{tabular}{|c|c|}
\hline Testimonial or vlog & $\begin{array}{l}\text { Individual speaking to camera about his or her reaction to Fitna, } \\
\text { understanding of Islam or other matters connected to the issue. }\end{array}$ \\
\hline Cut-and-mix & $\begin{array}{l}\text { Self produced video consisting of self made, or existing footage, pictures, } \\
\text { images, words and sound, combined into a new 'text'. }\end{array}$ \\
\hline Cut-and-paste & $\begin{array}{l}\text { Straightforward copy of existing footage from news, current affairs, } \\
\text { documentary, comedy, drama and other professionally produced } \\
\text { audiovisual material. }\end{array}$ \\
\hline Tagging and jamming & $\begin{array}{l}\text { Video carrying the tags 'Fitna' and/or (Geert) 'Wilders', meant to } \\
\text { complicate finding the original film (see below for further explanation). }\end{array}$ \\
\hline $\begin{array}{l}\text { Public speech or } \\
\text { sermon }\end{array}$ & Registrations of public speeches or sermons. \\
\hline Professional footage & $\begin{array}{l}\text { Video or films produced by professional media makers or by civic and } \\
\text { religious organisations, who use YouTube as one of their key distribution } \\
\text { channel. }\end{array}$ \\
\hline Other & Videos that do not fit one of the previous categories \\
\hline
\end{tabular}

In addition to the quantitative analyses, we focused on the testimonials or vlogs, cut-and-mix, and jamming videos for further qualitative examination, especially in order to describe in more detail what kinds of political and religious selves were performed in these videos, and what imaginary or real audiences were addressed. We left out the cut-and-paste videos, the professional footage and the registrations of public speech and sermons, because these appear to be using YouTube as a useful channel of re-distribution as part of existing practices of citizenship and are unlikely to tell us much about whether and how on-line forms of communication are inviting new modes of citizenship performance.

\footnotetext{
${ }^{8}$ The full coding sheet is available from our website.
} 


\section{Who is reacting to Fitna, in what way and with what message?}

Most of the videos carrying one of our search terms were uploaded close to the release data of Fitna. The average length of the videos is about 5 minutes, the average number of views is about 24.000 with a minimum of 40 for the least watched video (one of the Sorry-videos, see below) and a maximum of about 3,6 million for the most watched video, a piece to camera of an American standup comedian expressing his pride in being Muslim. In total over 10 million viewers watched one or more videos from our corpus, with almost 250.000 comments made altogether. These numbers show that YouTube was not a marginal platform in the controversy about Fitna. In combination with the data about the country of origin as registered by the posters, it also becomes clear that YouTube offered a global platform with almost half of the videos uploaded from the Netherlands, the US and the UK, and the other half from countries across the globe. ${ }^{9}$ The average age of the posters, as far as they listed it, was 32 years old, $82,5 \%$ of them registered as men, $9 \%$ as women, and $8,5 \%$ as unknown (the latter category frequently involves organisations as well as posters who do not wish to declare their gender). As in most participatory spaces of the Internet, a limited number of posters was responsible for uploading many different videos. A poster called Adilahmedibrahim, for instance, uploaded 81 videos about Islam in our corpus all of them tagged with (Geert) Wilders.

$44.6 \%$ of the videos in our corpus expressed explicit opposition to Fitna, over a third (38.3\%) did not address Fitna directly, about $6 \%$ were in favor Fitna ${ }^{10}$; these often involved reloads of (parts of) Fitna itself, translated into other languages, among which Spanish, Russian, Polish and Farsi. In total we found 44 re-uploads of Fitna itself or parts thereof. While a pro-Fitna position almost automatically meant an anti-Islam standpoint, anti-Fitna did not inevitably mean pro-Islam, nor did pro-Islam automatically mean an explicit protest against Fitna. In Figure 1 these relations are visualized more clearly with the bars showing the authors' position on Fitna (pro/anti/not about Fitna/unclear) along with their position on the Islam debate (pro/anti Islam or unclear):

\footnotetext{
${ }^{9}$ Netherlands, $28 \%$; US, $15 \%$; UK $8 \%$; Germany (4\%), Egypt (3\%), Canada (3\%), Pakistan (3\%), Australia (2\%), Sweden (2\%), Denmark (1\%), India (1\%), France (1\%), Morocco (1\%), but also Burundi, Poland, Kiribati, Singapore, France and Jordan.

${ }^{10}$ The remaining $10.8 \%$ was unclear.
} 


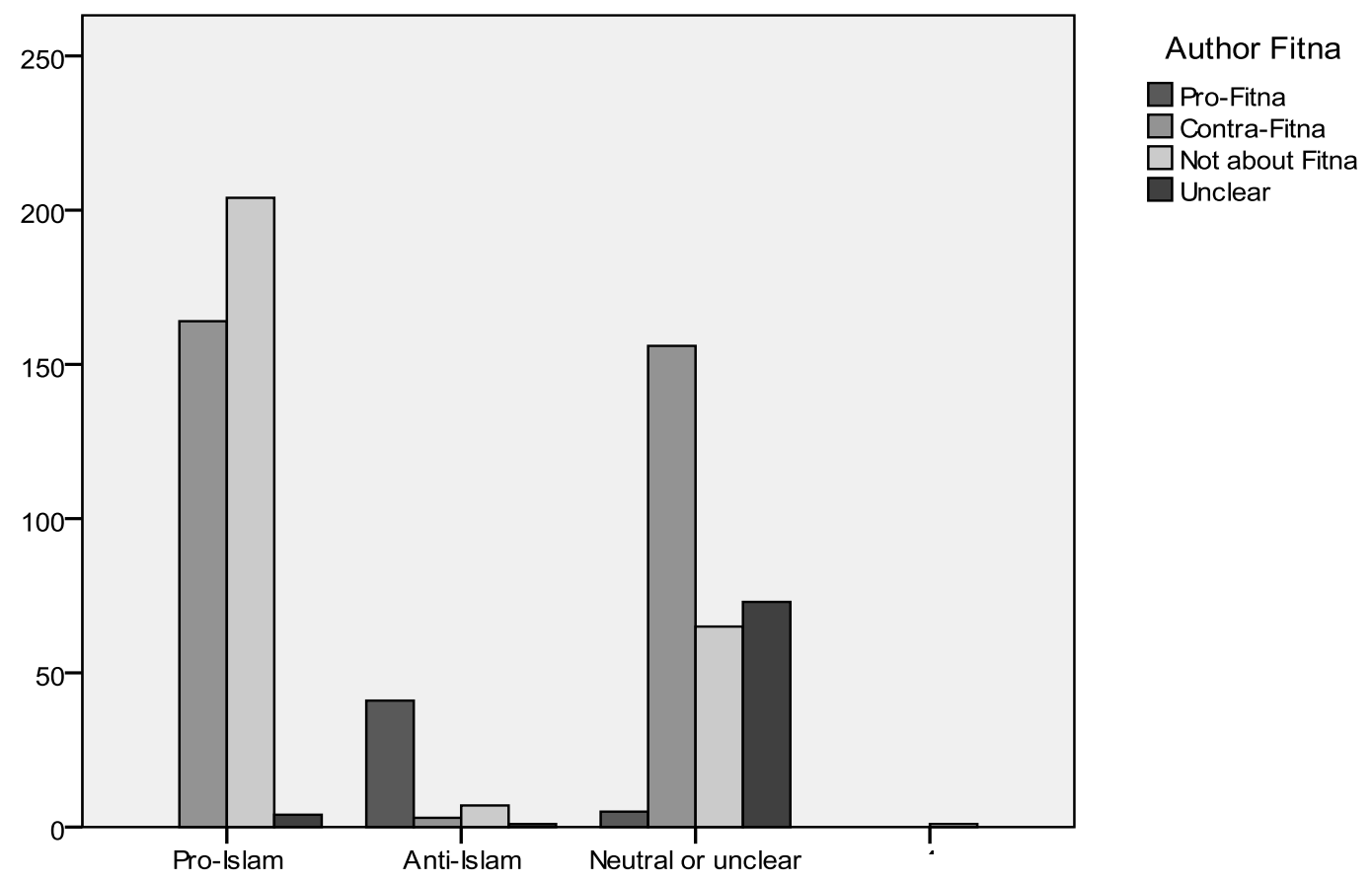

From Figure 1 it becomes clear that an anti-Fitna position is as strongly connected to a neutral or unclear perspective on Islam, as it is with a preference for Islam. ${ }^{11}$ These anti-Fitna videos thus involve both a religious and a political performance, the latter possibly in opposition to the values of Wilders and his film, as we will further examine in the next section. The figure also shows that the videos that do not contain direct references to Fitna are by and large positive about Islam and thus seem to perform a religious identity. One video, for instance, concerned an NBC news report about American women converting to Islam after $9 / 11$. The video was uploaded by users from, among others, Israel, France, Denmark, Germany, Australia, Japan and New Zealand, all referring the viewer to the same website for more information about Islam. Such a series of uploads based on one source video occurred more often. Re-uploads of earlier vlogs by American video maker Baba Ali for Ummah films, for instance, occurred regularly ${ }^{12}$, as did another video featuring a public reaction of Arabic talk show host Moez Masoud after the Danish cartoon crisis. ${ }^{13}$ The quantitative analysis further underlines this: most of the pro-Islam videos were copies of other footage (cut-and-paste). ${ }^{14}$

\footnotetext{
${ }^{11} X^{2}=631.4, p=.000$

${ }^{12}$ http://www.ummahfilms.com/, last visited April 9, 2010.

${ }_{13} \frac{h}{\text { For instance: } h \text { htp: //www.youtube.com/watch?v=uPxJ5NdELyo\&feature=related }}$

${ }^{14} \mathrm{X}^{2}=116.8, \mathrm{p}=.000$
} 
The general, quantitative insight into which political and religious selves are performed and in which way, can be specified further by a qualitative analysis of the three genres unique to online culture: jamming, cut-and-mix, and vlogging.

\section{Jamming and saying sorry}

In the wealth of YouTube uploads, videos explicitly saying 'Sorry' for Wilders' film were the easiest to frame as a performance of a political self that constructs its makers both as citizens of the Dutch nation state, and as people with a desire to speak and apologize to a global audience. These videos were part of a concerted action of a Dutch avant-garde multimedia company in Amsterdam, Mediamatic, that launched an initiative to make many movies called 'Fitna', already before Fitna was actually released:

"Why? Well we can't stop Wilders. ... Actually, we do not want to stop his movie because we cherish our freedom of expression. Even stupid populist politicians have fundamental rights. Especially they! We can compete for attention however. And we can produce disinformation. So we are going to make Movies called "Fitna" in which we apologise for Geert Wilders embarrassing behavior. We will make so many of them that it will be hard to find the movie by Wilders without finding lots of movies apologizing for it.... Let's smother this Wilders in our apologies. If we work hard enough, no one will be able to find his crap among all the noise we produce. And the world knows how we feel about Wilders and his opportunism."15

Mediamatic also organized offline events to enable people to make short sorry-videos and the initiative was reported in most Dutch newspapers. These videos usually last no longer than 15 to 20 seconds. They look and sound like amateur recording and come in three standard forms: in the first type we see one or more persons wearing a blond wig (as a parody on Wilders' bleached hairdo) saying, singing and often giggling 'sorry', in front of a black-on-white wall text reading 'I am sorry'; the second type shows uses a screen wide carton Dutch flag with a round whole in it through which a person puts his or her face and says 'I am sorry'; the third type shows takes from an outdoor manifestation in which people carrying the wig say 'sorry' in the camera.

All these videos were given the labels 'Geert Wilders', 'Fitna' and 'Sorry', and they come up when one searches YouTube for 'Geert Wilders' and 'Fitna'. The numbers of views and comments suggest that this collective effort to jam Fitna and offer an immediate antidote has been successful.

${ }^{15}$ http://www.mediamatic.net/page/33851/en, last accessed April 3, 2010. 
While some of these videos were accessed only a dozens of time and were left without comments, others drew twenty to thirty thousands hits and were commented on vividly. ${ }^{16}$ In addition, a number of people did not participate in the organized Mediamatic productions, but made individual videos copying the 'sorry' idea, or tagged videos with completely unrelated content with titles and labels about 'Wilders' and/or 'Fitna'. One six second video, for instance, titled 'Fitna, the movie by Geert Wilders', shows a woman in an office setting, carrying a white coffee tray on her head and saying 'sorry' into her webcam. Other videos morphed pictures of Wilders, overwriting them with big SORRY letters, or mixed cartoons and audiotapes saying sorry.

What do people say about themselves by posting such videos or participating in the collective MediaMatic project? Through apologizing for Wilders and his video they are basically saying: 'we are not like this'; the humorous format with the blond wig is an additional key attribute through which distance and contempt for Wilders is demonstrated. The audience addresses is a global one, as the explanatory comments of MediaMatic show, and as is further underlined by the use of English language - 'I am sorry' - instead of the Dutch. While there is no formal global entity that is addressed, both the performance and the assumed global audience suggest the desire of the participants to connect to an imagined global community. The particular qualities of digital culture offer such connections: the solution is not to ban Fitna, but to make it impossible to find; a bit like hiding an undesirable book in a library instead of burning it. It is a performance in the context of organized protest that does not need much practical work, nor much cognitive or emotional investment, and says little else about who the posters are. 15 seconds of global citizenship, so to speak, for each individual, which nevertheless collectively adds up to political protest with a global reach.

\section{Cut and mix}

The cut and mix videos are other typical products of digital culture and abound in the YouTube responses to Fitna. They range from childlike drawings and words in primary colors, to sophisticated re-combinations of existing footage, text and sound; they vary between serious to satirical but most of them express an anti-Wilders or anti-Fitna position (60\%). The satires include Shitna, Sint the movie, Lidna the movie or Fitna the sitcom. In Fitna the Sitcom, for instance, the original Fitna film is shown but with an audio track of studio audience laughter, bursting out after each horrible image in Fitna, and therewith seriously undermining the threat the film tries to convey. The video is a one-off

16 The videos themselves do not explain these differences, since they all had the same content and style; with the data at hand there is no way of telling why the one video drew so many more views than the other. 
product of someone who subscribed to YouTube only to upload this three and a half minute film. Satire is often described as aimed at ridicule and critique in order to expose the flaws of - often religion or politics. The satirical YouTube videos are obvious performances of a political self; by definition of the generic features of satire, the videos are contemptuous as is evident in concrete $a d$ hominem attacks on Wilders himself. In some videos pictures of him are morphed, in others he is impersonated as speaking about human rights for Smurfs, portrayed as the evil brother of Chuckie ${ }^{17}$ or as himself in parliament with a funny sounding voice-over claiming that he will ban Sesame Street. In more aggressive attacks on Wilders, his video is compared to the propaganda of the Nazi's, which happens for instance in cut-and-mix productions called 'Adolf Wilders Fitna', or 'Geert Hitler'. One whole channel is specifically dedicated to making anti Geert Wilders videos, and is maintained by someone called 'verwildering', which is a Dutch pun on Wilders' name which means degradation or dehumanization. One such video is a still picture of Wilders combined with a traffic ban sign, and a parental advisory sticker and a swastika pasted over Wilders' face. The image is uploaded three times with different audio-messages: one techno house rap ('when you run into Wilders, slap that Bitch'), one Afghan rap ('Jihad on my mind when I pop at ya, I think you're blind, check you're optical') and another 'diss' rap ('middle finger in the sky for Geert Wilders'). ${ }^{18}$ As these examples show, the cut-and-mix videos are often the product of young individuals using the codes and conventions of youth and popular culture to make their point, in more or less sophisticated ways. The style of choice is parody and satire, morphing of pictures and 'dissing' (putting someone down) in videos that take their inspiration from rap genres. The argumentation is usually not very elaborate (in one video the main text is 'we don't want discrimination' ${ }^{19}$ ), but through sound, visuals and lyrics strong critical emotions (anger, fear) against Wilders are expressed.

There are a notable exceptions to his general tendency in the cut-and-mix videos, and those concern the Bible versions of Fitna, titled, for instance, Fitna (Bible version), Fitna the movie (what about the bible?) Geert wilders the movie Fitna "Bible version", or Fitna-Schism (The Bible version of Fitna). Of these, the latter - Schism - is the best-known and most popular one,, which we found reuploaded nine times in our corpus. It was made by Saoudi blogger Raed Al Saeed: 'This is a movie I made in less than 24 hours in response to Geert Wilders's Anti-Islam Movie "Fitna"', the argument being that it is easy to make such videos with other holy books. ${ }^{20}$ The video shows footage of American soldiers beating up civilians in their compound and a US evangelic group led by a blonde woman teaching children to become soldiers for the Christian war. When he posted his video on

\footnotetext{
${ }^{17}$ The evil doll of the Child Play movies.

${ }^{18} \mathrm{http}: / / \mathrm{www}$.youtube.com/user/verwildering, last accessed April 7, 2010.

19 http://www.youtube.com/watch?v=0ZgCwhuD4Rs, last accessed on April 7, 2010.

${ }^{20} \mathrm{http}: / /$ www.youtube.com/watch?v=uWPg Kill7Q
} 
YouTube, it was first removed for 'having inappropriate content', but after Al Saeed claimed that Fitna should then be banned as well, the video was put up again. ${ }^{21}$ Schism and the other Bible versions of Fitna, have a similar structure to Fitna, using brutal quotes from the Bible and interspersing them with images of violence, often footage from the invasion in Iraq and occupied Palestine, but also fast changing footage showing different animal predators often attacking and killing prey set to dramatic classical music. According to these videos or additional information given by the posters the purpose is not to vilify the Bible or Christians. Instead their aim was to show that one could abuse the Bible in a similar way as Wilders abused the Quran, to claim that Christianity is by definition a violent religion. Hence, the Saudi Arabian poster quoted above says how easy it was to make his Bible film. Other videos similarly deconstruct the demagogy of Fitna, analyzing 'the outplayed and cheap tactics' to discredit Islam, ${ }^{22}$ for instance, by showing how the Quran verses that Wilders uses are quoted out of context. ${ }^{23}$ Inevitably, one poster reacted again to these Bible varieties, making a video asking Fitna or Schism and claiming that Fitna or Schism is not about religion but about politics. The video ends with a picture of U2 singer Bono carrying his Co-exist blindfold. ${ }^{24}$

While the satirical cut-and-mix videos basically make an appeal to audience emotions such as anger or contempt, the Bible versions of Fitna are built on the assumption that it can be explained and shown to audiences that Fitna is a demagogic representation of Islam, and that such negative propaganda can be produced using the Bible as a source as well. It is an appeal to cognition and reason of audiences.

\section{Testimonials}

The Sorry videos and the cut-and-mix productions were made specifically to react to Fitna. The testimonials about Fitna were more often part of an embedded institutional or individual practice of vlogging. British comedian Pat Condell, (in)famous for his anti-religious comedy, uses YouTube instead of live performance for his 'Godless' jokes. In one of his videos he responds to Fitna for 6.49 minutes, supporting the film's point that Islam is violent ('Islam without violence is like an egg-free omelette') and scorning all the 'headless chickens' who dare not speak up. ${ }^{25}$ Through this and his other videos Condell performs a staunch anti-religious self who is on a mission to discredit all

\footnotetext{
${ }^{21}$ Some links to the video still require the visitor to register as over 18 (dd. April 12, 2010)

22 http://www.youtube.com/watch?v=z2806UldCJE, last accessed April 7, 2010.

23 http://www.youtube.com/watch?v=ngGf3HRhneg\&feature=related, last accessed April 7, 2010.

24 http://www.youtube.com/user/kellibelli530, last accessed April 9, 2010.

${ }^{25} \mathrm{http://www.youtube.com/watch?v=OxbYBIIT6VE \& feature=related,} \mathrm{last} \mathrm{accessed} \mathrm{on} \mathrm{April} \mathrm{6,} 2010$.
} 
religions and believers, including Islam and Muslims. It is a performance of a political identity that is clearly incompatible with religious identity and speaks to his usual fans, but also to an assumed audience of non-believers.

Another stand-up comedy that came up with our search terms, was a particularly popular video produced by the Muslim American Society (MAS) in which a young man, standing on stage in front of a dark background with the camera frequently showing his face in close up, starts speaking facing the camera: ' $\mathrm{Hi}, \mathrm{I}$ am not a terrorist or a date merchant, I don't live in a tent or keep my wife zipped up in it everyday, and for the record, I knew who she was before I married her'. This ironic beginning, strongly enhanced by the various items (camel, tent, white robe) appearing on screen when mentioned, is a clear address to the stereotypes that many people hold about Islam and shows a willingness to present an alternative, modern understanding of Islam. Halfway through the video the tone changes from humorous to a emotional praise of Islam, and the scientific and cultural achievements of Muslims, ending in the proud declaration: 'My name is Muhammed and I am a Muslim'. The self that is constructed here is that of a Muslim who does not experience nor acknowledge stereotypes of Islam as a religion that is at odds with the values of US society: 'Trust me, I would go back to my own country, but I am already in it', after which a picture of the US flag is inserted. The video is a perfect example of the performance of a religious self that also articulated a democratic and inclusive political self: 'I believe in peace; I believe in people of all different religions and beliefs living together in harmony'. ${ }^{26}$

Many of the vlogs came from societal and religious organisations, and from individuals who are regular vloggers. Their videos and their performance of politics and religion vary as much as their organisations and projects. Only occasionally, we found a video that could be considered an occasional one-off vlog. A particularly telling one comes from a young white Dutch man, who posted his video the day after the Fitna release. His video starts with a text in white font on a green background: 'My perspective on this movie and the controversial topic of religion and islam in today's society. (I have typed down my perspective and read it out loud, therefore it seems a bit 'from reading';)). The preparation and typing of the text beforehand suggests cognitive and presentational effort, a strong investment in the issue, and an implicit acknowledgment that this may be an uncommon gesture among the more informal styles of YouTube. The ensuing seven minutes shows the young man in medium close up in a dim lit room, who begins his reading with 'Hello, I am Dutch and I wonder why people get Islamophobia'. The nationality statement is exceptional; it connects the speaker not only to Wilders, who is also Dutch, but also works to make clear to the

\footnotetext{
${ }^{26} \mathrm{http}: / /$ www.youtube.com/watch?v=JQXh200uhlc, last accessed on April 6, 2010, viewed 3674342 on that date.
} 
wider community of Fitna posters that there are other Dutch non-Muslim voices from the Netherlands that do not support Wilders. He then articulates how differences between people are tied up with power, hatred and ignorance ('the root of all evil'), and expresses the shock he felt while watching Fitna, especially regarding Wilders' ignorance about a world religion. Using a verse from the Quran he endorses peace and understanding between people, civilizations, nations and religions, 'no matter what, humanity first. Thank you for listening, bye. ${ }^{27}$ This is a video that shows the poster performing both as a political self by expressing his views on Wilders and as a citizen to the emerging community by welcoming his audience, apologizing for his (reading) mode of address and thanking them for their attention.

\section{Discussion}

In this contribution, we claimed that the current multimedia environment makes it necessary and possible to think of citizenship as a performance, in addition to citizenship as a status within the boundaries of a nation state, or as an acknowledged identity within a more or less demarcated polity. In the context of global controversies, crises and conflicts there are no 'citizens' in the traditional sense of inhabitants or members of a world polity, nevertheless there are many people who feel that they are key stakeholders and want to express their engagement. Together, they constitute the community of all those 'affected by principle' who should have a chance to participate if a debate is to be considered truly 'public' (cf. Frazer 2007). The border-circumventing, highly visual digital technologies make such participation easier as was clear in our analysis of the hundreds of video reactions to the vicious anti-Islam movie Fitna, made by a member of the Dutch parliament. The sheer numbers of YouTube activities around Fitna (videos, views and comments) demonstrated that this was not at all a marginal phenomenon within the wider Fitna and Wilders controversies, making the question as to what these videos mean, or - to be more precise - for which contexts the posters make them meaningful, all the more pressing.

We approached the videos uploaded in response to Fitna, as acts and practices in a placeless public debate, in which people claimed their right to speak and perform their political and/or religious selves, in connection to an assumed audience. It is in connection to these assumed audiences that citizenship may or not may emerge. As Hartley suggests in this volume, citizenship can be approached as 'an association of strangers', and in the case of our YouTube videos the question thus is whether and how this association with the 'stranger/audience' is enabled by the videos. We

27 http://www.youtube.com/watch?v=Fzbs2uN aXI, , last accessed April 6, 2010, see for a similar case: http://www.youtube.com/watch?v=eY717N-rcl4. 
found, on the basis of our quantitative analysis, that the most common YouTube reaction for Muslims was to upload copies of videos that expressed their own understanding of Islam as a peaceful religion in contrast to the picture drawn by Wilders. In many of these cases, the video did not directly address Fitna or Wilders, but the titles and tags that the posters added to their videos made clear that they performed their religious selves in the context of Wilders' and other anti-Islam messages. Their videos thus perform a kind of citizenship, an outreach to strangers as it were, that is based on the desire to present a true picture of oneself to others, and to solve misunderstandings. Our more detailed analysis of the video genres unique to visual digital culture (tagging/jamming, cutand-mix and vlogs) showed that each invited their own kinds of political and religious performances, and assumed particular traits and interests of their audience. The jamming videos saying sorry were unique digital means of activism, enabling a particular participation in the controversy around Fitna that assumed a global audience open to apology. It can be seen as a performance of a civic virtue that Allison Jaggar (2000) has identified as crucial for citizenship in multicultural societies, that is cultural recognition, which entails the willingness and capacity to align with the experiences of cultural 'others'. The apologies in the Sorry videos testify in that sense of an understanding, on the side of the posters, of the damaging effects of stereotypical and insulting representation of Islam on its adherents. The cut-and-mix videos, appeared to be especially welcome means for satire and parody demonstrating both the posters' immersion in global popular culture, and their political selves in protest to Geert Wilders and his anti-Islam project. The particular performance of citizenship taking place here, has historical roots going back at least to the $17^{\text {th }}$ century satirical pamphlet culture which attacked many a royal or regent in power, and which has undermined dominant political culture ever since. While these kinds of cut-and-mix videos primarily addressed audience emotions (anger, fear, contempt), the Bible cut-and-mix videos positioned audiences as cognitively competent and capable to disentangle the visual demagogy in Fitna. Together with the vlogs, these videos are best understood as performances of well informed selves articulated with a classic modernist understanding of citizenship, addressing others equally well informed or - at least willing to be informed. It ties these videos and vlogs about Fitna, to a classic conceptualization of the public sphere, as the term 'vlogosphere' as it has been called in analogy with the blogopshere (Griffith and Papacharissi, 2010) suggests.

These cases demonstrate that the YouTube videos cannot be typified as enabling one kind of citizenship performance; we found several ones instead that nevertheless have one thing in common and that is their assumption about an audience out there. This implies a fundamental 'connectedness' of the YouTube performances that takes two forms: that of real connections to an already existing practice of religious and political participation, as is clear from the videos connected 
to the vlogosphere and from the many online manifestations of Islamic faith, and that of individual, one-off acts of video participation in the Fitna controversy and the assumed virtual audience. A desire to make a connection to dispersed others is thus what binds both the occasional acts and embedded practices of political and religious performance in reaction to Fitna on YouTube. A further commonality is that these attempts are molded in cognitive, emotional, humorous, denigrating, amiable, absurdist and other ways, but that none of them were violent or aggressive. Although we found many references to Wilders as Hitler, we did not find videos actually engaging in neo-Nazist hate speech; similarly, while many videos showed Islamist terrorism there were none in our data that supported extremist Islamism and propagated violence. Obviously, such videos do exist, but they did not come up in this YouTube debate. As the initial removal of the Schism video suggests, this maybe as much the result of enforcement of the YouTube user guidelines, as it could be of the way the posters want to make connections, within the admittedly wide boundaries of online civility (Papacharissi, 2004).

We propose, in closing, that it is in this context of such attempts at 'connectivity' that the online performance of political and religious selves can become particular acts and practices of (unlocated) citizenship; citizenship that is not defined by its relation to an institutional or communal entity, but that takes its form with respect to dispersed other people, in the double sense of that word. In the classic 'rights' and 'obligations' terminology of citizenship, and articulated with the affordances of YouTube, this would involve both the right to speak/show and the obligation to listen/watch. While the sheer numbers of production and consumption of the videos suggest that that is exactly what happened with the Fitna responses, such a notion of citizenship as connectivity need to be further explored by looking at the particular patterns of interaction between the posters and their audiences, as they subscribe to each others channels, react to each others videos and discuss among each other. These are the questions for a subsequent investigation about the YouTube responses to Fitna. 


\section{$\underline{\text { References }}$}

Barna Research Group (2001). More Americans are seeking net-based faith experiences. http://www.barna.org/FlexPage.aspx?Page=BarnaUpdate\&BarnaUpdatelD=90

Bunt, G. R. (2009). iMuslims: Rewiring the house of Islam. London: Hurst \& Company.

Butler, J. (1990). Gender Trouble. London: Routledge.

Chadwick, A. \& Howard, P. N. (Eds). (2009). Routledge Handbook of Internet Politics. London: Routledge.

Cheong, P. H., Halavais, A. \& Kwon, K. (2008). The Chronicles of Me: Understanding Blogging as Religious Practice. Journal of Media and Religion, 7(3), 107-131.

Eliasoph, N. (1998). Avoiding politics: how Americans produce apathy in everyday life. Cambridge University Press.

Ericson, R., Baranek, P. M. \& Chan, J. B. L. (1989). Negotiating Control: A study of news sources. Toronto: University of Toronto Press.

Frazer, N. (2007). Transnationalizing the Public Sphere: On the Legitimacy and Efficacy of Public Opinion in a Post-Westphalian World. Theory, Culture \& Society 24(4): 7-30

Griffith, M. \& Papacharissi, Z. (2010). Looking for you: an analysis of video blogs. First Monday, 15 (1). http://firstmonday.org/htbin/cgiwrap/bin/ojs/index.php/fm/article/view/2769/2430 (accessed 12 April, 2010).

Hirschman, A. (1970). Exit, Voice and Loyalty: responses to decline of firms, organizations and states. Cambridge, MA: Harvard University Press

Hirzalla, F. (2007). The Internet and Democracy: Participation, Citizens and Politics. Javnost - The Public, 14(2), 83-96.

Hoover, S., Schofield Clarke, L. \& D. Rainie (2004). Faith Online. Washington: Pew Internet and American Life Project. Available at: http://www.pewinternet.org/pdfs/PIP_Faith_Online_2004.pdf

Isin, E. F. \& Nielsen, G. M. (Eds.) (2008). Acts of Citizenship. London: Zed Books.

Keren, M. (2006). Blogosphere: The new political arena. Lanham, MD: Lexington Books.

Knott, K., Poole, E. \& Taira, T. (2010) 'Multiculturalism, identity and freedom of speech: the Case of Geert Wilders'. Presentation at Loughborough University, March 9, 2010.

http://pebblepad.staffs.ac.uk/viewasset.aspx?oid=66768\&type=blog

Lövheim, M. \& Lindermann , A. (2005). Constructing religious identity on the internet. In Hojsgaard, M. \& Warburg, M. (Eds). Religion and Cyberspace. London: Routledge.

Papacharissi, Z. (2004). Democracy On-line: Civility, Politeness, and the Democratic Potential of Online Political Discussion Groups. New Media \& Society. 6(2), 259-284. 
Paolillo, J. C. (2008). Structure and Network in the YouTube Core. Proceedings of the 41st Annual Hawaii international Conference on System Sciences (January 07 - 10, 2008). HICSS. IEEE Computer Society, Washington, DC, 156.

Poole, E. \& Richardson, J. E. (Eds.) (2006). Muslims and the News Media. London: I.B. Tauris.

Rheingold, H. (1991). Virtual Reality: The Revolutionary Technology of Computer-Generated Artificial Worlds - and How It Promised to Transform Society. London: Simon \& Schuster.

Rheingold, H. (2000). The virtual community: homesteading on the electronic frontier. Cambridge, MA: MIT Press.

Richardson, J. E. (2004). (Mis)Representing Islam: The racism and rhetoric of British broadsheet newspapers. Amsterdam: John Benjamins Publishing Company.

Ruigrok, N. S., Scholten, O., Krijt, M. \& Schraper, J. (2009). Fitna in de media: een brongerichte mediahype [in Dutch]. Tijdschrift voor Communicatiewetenshap. 37 (3), 238-253.

Schudson, M. (1998). The Good Citizen: A History of American Public Life. New York: Free Press.

Van Zoonen, L. (2005). Entertaining the citizen: When politics and popular culture converge. Lanham, MD: Rowman \& Littlefield Publishers.

Van Zoonen, L. (2007). Audience reactions to Hollywood Politics. Media, Culture \& Society, 29(4), 531-547.

Van Zoonen, L. Müller, F., Alinejad, D., Dekker, M., Duits, L., van Romondt Vis, P., \& Wittenberg, W. (2007). Dr. Phil Meets the Candidates: How Family Life and Personal Experience Produce Political Discussions. Critical Studies in Media Communication. 24(4), 322-338.

Van Zoonen, L., Müller, F., \& Hirzalla, F. (2009). De slag om Fitna [Fitna, the video battle]. In M. Aarts and M. van der Haak (Eds.). Popvirus: popularization of religion and culture. Amsterdam: Aksant Publishers.

Vis, F., Thelwall, M., van Zoonen, L. \& Mihelj, S. (2010). Challenging dominant representations of Islam online: innovative methods for studying YouTube. Innovative Methods in the Study of Religion Conference, London, 29-30 March.

Vis, F., Van Zoonen, L. And S. Mihelj (2009, under review). Women responding to the anti-Islam film Fitna: voices and acts of citizenship on YouTube. Paper presented at the ECREA Media and the Spectacle Conference, Rotterdam, November. 